\title{
Learning Three-Dimensional Shapes in Geometry Using Mobile-Based Augmented Reality
}

\author{
https://doi.org/10.3991/ijim.v14i09.13035 \\ D. Rohendi $(\bowtie)$, Y. Wihardi \\ Universitas Pendidikan Indonesia, Bandung, Indonesia \\ dedir@upi .edu
}

\begin{abstract}
Learning three-dimensional (3-D) shapes in geometry are essential to improve students' spatial abilities. However, the concept of three-dimensional shape is still considered as a difficult topic to be taught by some math teachers and to be learned by students in Indonesia. Therefore, an alternative media which can facilitate the learning process of geometry is required for teachers and students so that they can easily understand the concept. This present study attempts to implement mobile-based augmented reality (AR) as a media which can aid junior high schools' teachers and students, specifically, in comprehending the concept of three-dimensional shapes in geometry for knowing students spatial learning activities. The results of the study reveal that by using mobile-based augmented reality can increase students spatial learning activities.
\end{abstract}

Keywords - Augmented reality, geometric shapes, mobile-based, spatial ability, three-dimensional shape.

\section{$1 \quad$ Introduction}

The three-dimensional (3-D) shape is one of many concepts in geometry which is taught in junior high schools in Indonesia. This concept introduces students to recognize geometric objects, problem-solving abilities, and other mathematical abilities [1]. These abilities are vital in human life. Geometry appeals to visual, aesthetic and intuitive senses, which are intimately connected with the development of mathematics [1]. Geometry is one of the practical elements in mathematics. Studying geometry suits to improve one's mathematical abilities [1]. Learning geometry is also considered as an important activity to improve spatial ability. Spatial ability is the ability to generate, retain, retrieve, and transform well-structured visual patterns. It is an essential component of human intelligence and it hugely influences Science, Technology, Engineering, and Mathematics (STEM) domains [2]. It may give a new perspective of spaces and provide a way to interpret and reflect on our physical world. Although this ability is one of the important human abilities, it is difficult to develop it. Many studies show that providing students with geometry learning activities proven as a powerful strategy to improve students' performance in spatial ability tasks [3]. However, these activities generally require skills to generate and manipulate three-dimensional mental images from two-dimensional (2-D) objects which may cause some difficulties for some 
students [4]. Furthermore, there is an assumption that geometry or mathematics is one of the most difficult subjects and it is not preferred by most students [5].

Technology has influenced the process of learning in the last decade. Various tools are widely used to enhance the results of students' performance, such as mobile tools and mobile instructional [6], cyber blog [7], and augmented reality [8]. Augmented reality (AR) is a kind of technology that is capable to combine and overlay computergenerated content onto the real-world object or real-world environment. It allows displaying both 2-D and 3-D objects and showing every part of the objects in various viewpoints. Moreover, this technology could be combined with mobile technology, so it can give more experience to the user [9]. The studies focusing on the use of MobileBased Augmented Reality (MB-AR) in mathematics, especially in geometry is still very limited. AR has many advantages that can be utilized for learning purposes [10]. With AR's advantages, teachers are expected to teach geometry easily which makes students can quickly understand the concept of geometry, especially concerning the concept of 2-D and 3-D shapes.

Cell phone technology is developing very rapidly today [6] and is broadly used by almost everyone worldwide including students in schools. Generally, students have accustomed to using a camera in their cell phones with advanced technology such as Android. However, it is usually used merely for entertainment purposes, such as playing games, opening video websites, or taking selfies [11]. Thus, it can be said that the use of cell phones for learning purposes is still limited, when in fact; it is possible to be utilized for learning processes. By considering these advantages, a tool can be created to assist the process in learning geometry and hopefully help students overcome the difficulties in understanding it. This present study exhibits a type of mobile-based augmented reality to learn three-dimensional shapes in geometry which is different from other conventional learning media. The mobile application can visualize the nets of 3 D shapes through animations as well as the vertex, edges, space diagonals, and diagonal plane of 3-D objects. All of the objects can be viewed in all directions by using mobilebased augmented reality. In particular, the system uses unity $3 \mathrm{D}$ and vuforia AR software as the development platform. This media is expected to make geometry learning easier and more attractive to students.

\section{Literature Review}

\subsection{Three-dimensional shapes in geometry}

The concept of volume and surface areas of three-dimensional shapes in geometry are still difficult to be grasped by some students ([12]; [13]; [14]), for example, calculating the surface areas and volumes of cylinders, prisms, pyramids, and cones. Students mostly are still facing difficulties in understanding these geometrical concepts. Most teachers only use conventional media or books in teaching these concepts so students find it difficult to visualize the whole areas of three-dimensional shapes, especially when they want to observe and calculate various parts of a certain shape such as the inner side, diagonal, and space diagonal of the 3-D shapes. 3-D shapes are often found 
in daily life; therefore, the concept of 3-D shapes should already be understood by students. Three-dimensional shapes in geometry are studied at school in Indonesia because this concept is required by students so that they can identify the geometric objects that they later will encounter in real-life.

\subsection{Spatial ability}

The ability resulting from studying geometry is the spatial ability or the ability to examine geometric spaces. This is a basic ability for students [15] so that by understanding the concept they can interact and adapt well with the surroundings. To develop this ability, teaching and learning processes are required to be properly managed. Nonetheless, in reality, teachers do not have an adequate ability to teach geometry by relating to its application in real-life [16]. In addition, many students in Indonesia face difficulties in understanding this concept. Spatial abilities include understanding three-dimensional shapes. The accomplishment of this ability is characterized by the capability of students in identifying the three-dimensional shapes including their elements. The spatial ability of three-dimensional shapes can be classified based on its objectives:

- The characteristics or properties of the shapes.

- The use of appropriate terms to describe geometric shapes, depending on the level of students' thinking abilities.

- The ability to show the evidence of geometrical thinking in solving puzzles, exploring shapes, designing, and analyzing shapes.

- The ability to recognize shapes in their environment.

- The ability to solve problems.

Spatial ability is an essential mathematical ability, especially in geometry. There are numerous definitions of spatial ability:

- Able to analyze the geometry characteristics and properties of both two-dimensional and three-dimensional.

- Able to construct mathematics arguments concerning geometric relationships and so on.

- Able to identify, classify, compare, and analyze the characteristics of properties and relationships of one, two, and three-dimensional geometric shapes [17].

\subsection{Augmented reality}

Augmented Reality (AR) technology is a combination of the real world and the virtual world ([18]; [19]; [20]). AR is currently used in various fields of science and training that require simulations. In the educational field, AR has also been used from basic education to tertiary education. Several studies present that AR can increase students' attention [21] and motivation [22]; [23]. AR allows the users to see the real situation, through the created virtualization [24]. The use of AR in learning processes is still very limited, whereas one of the advantages of AR is to improve the quality of learning in 
schools and even universities. Moreover, it can especially be used by schools that have limited laboratory equipment.

Mobile-based AR (MB-AR) used in this study is the result of the development done by the previous researchers. This MB-AR comprises of two parts namely MB-AR Android-based application which is stored in cell phones and a magic book. MB-AR Android-based application is integrated to a camera phone and works to recognize the markers on the magic book. On the other hand, the magic book can be used a guideline for students in learning 3-D shapes in geometry. When students want to see the visual of 3-D shapes based on the materials that they learn, they can highlight the anime image using a camera attached in the Android phone that has MB-AR application.

\section{Methodology}

This study attempts to implement a mobile-based augmented reality media to the process of learning mathematics in middle school. MB-AR serves as a learning aid to explain the concept of 3-D shapes. The development of MB-AR media is explained in this study and has been considered appropriate to be used in the learning processes. The media has been assessed by material experts, media experts and has been previously tested on students. The MB-AR media has been used by 150 junior high school students in Bandung, Indonesia, during their learning processes. To uncover their spatial learning activities, all students are observed when they are learning 3-D shapes in geometry. In this learning observation, the elements which are investigated consisting how students analyze the characteristics of geometric objects; construct mathematical arguments geometrically; identify, classify, and compare geometric shapes; transform and use the media systematically in analyzing mathematical situations geometrically; and visualize, think spatially, and model the concept of geometry on problem-solving. The learning process is carried out in 3 stages and each of them is observed. These three stages discuss different materials that will be described. The first stage focuses on the discussion of cube and cuboid. Then, students' spatial learning activities are observed. The second stage talks about pyramid and prism. Similarly, after that, the observation of spatial learning activities are examined. On the third stage, the material concerning surface area and volume of the 3-D shapes are discussed. As it has been conducted on the first and second stages, spatial learning activities of students are investigated following the discussion of the material. The results of students' spatial learning activities observation are then added in terms of each characteristic and stage. The sum then is converted into percentages and categorized based on the type of spatial learning activity. By having the percentage of students' spatial learning activities from stages 1 to 3 , the development of their results can be examined. 


\section{$4 \quad$ Result and Discussion Review}

\subsection{Mobile-based augmented reality media}

The steps in producing MB-AR that can be utilized in learning processes begin with the analysis of the user, material, software, and hardware, followed by designing, developing, and testing [25]. User analysis is conducted to discover the characteristics of users who will later use MB-AR. It is carried out to see if the AR display design meets the users' preferences; whether the users are interested in the AR display, and whether the users will possibly have any difficulty in operating the AR. Material analysis is intended to estimate the format of the material that is suitable for MB-AR display whether it is a video, text, graphic, or other formats. The determination of the format of this material is adjusted to the abilities that are expected to be achieved by the students after using MB-AR in learning processes. The next step is software and hardware analysis. This analysis is intended to determine and anticipate whether the software and hardware used in MB-AR are suitable with the characteristics of the user's software and hardware. This step must be performed so that when MB-AR is used by the user, it will be compatible with all software and hardware owned by the user. Additionally, this MB-AR can be used for a long time which means that although software and hardware continue to develop, this MB-AR can continuously be used for the next few years. This analysis step is an anticipatory step that is required to be completed in the development of the MB-AR so that the media will meet the user's needs.

The next step in developing MB-AR is designing. In this step, the design of flow charts, storyboards, interface views, menus, and icons of the MB-AR are developed. The next step is to design the material that will appear in MB-AR. The MB-AR is developed to train junior high school students to understand spatial concepts, so the materials will be shown in the form of simulation and animation. The format of the material, which is in the form of simulation and animation, allows students to learn the concept of geometry more comprehensively. Furthermore, the learning processes will be encouraged by the advantages of AR, where the form of geometric shapes can be seen from various points of view. Therefore, by learning about 3-D shapes using MB-AR, it is expected that the spatial ability of students in geometry can be further trained. After the design step is complete, the process is followed by MB-AR development. MB-AR development uses unity $3 \mathrm{D}$ and vuforia $\mathrm{AR}$. This platform is chosen because its practicality so the MB-AR can be accessed via an Android phone. Another consideration for the development of the MB-AR is to allow students accessing the MB-AR anywhere and anytime depends on the users' needs. The final step in this media development is testing. The testing process is conducted based on the judgment of media experts and material experts. The results indicate that MB-AR is considered appropriate for learning activities.

The MB-AR is developed using markers in the form of anime images which are very popular among middle school students, such as is shown in Figure 1. 


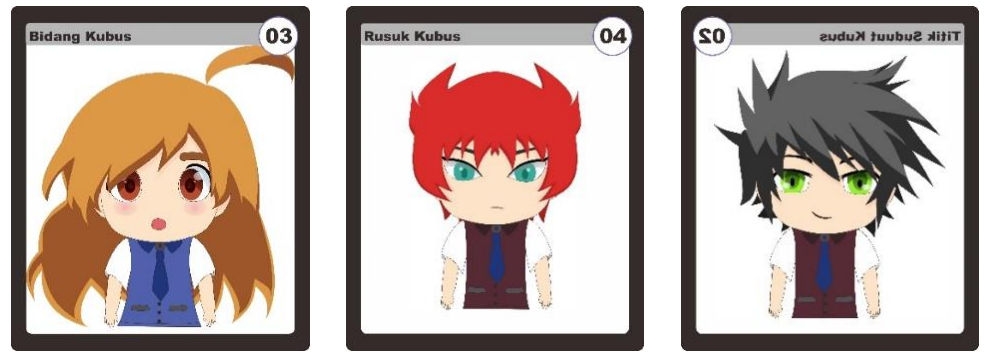

Fig. 1. Anime characters used for markers in MB-AR

If the anime character in Figure 1 is scanned using a cell phone camera, it will directly display the image of three-dimensional shapes above the character. The order of the appearance of the three-dimensional shapes is following the order of materials presented in the MB-AR student handbook. The marker that is used is in the form of a figure which is deliberately made to display three-dimensional objects. The three-dimensional objects which are covered in the lesson include cubes, prisms, cuboid, pyramids, and cones. In this lesson, students learn how to determine the face diagonal, space diagonal, height or altitude, and slant height on three-dimensional objects. The AR media illustration used is presented in Figure 2.

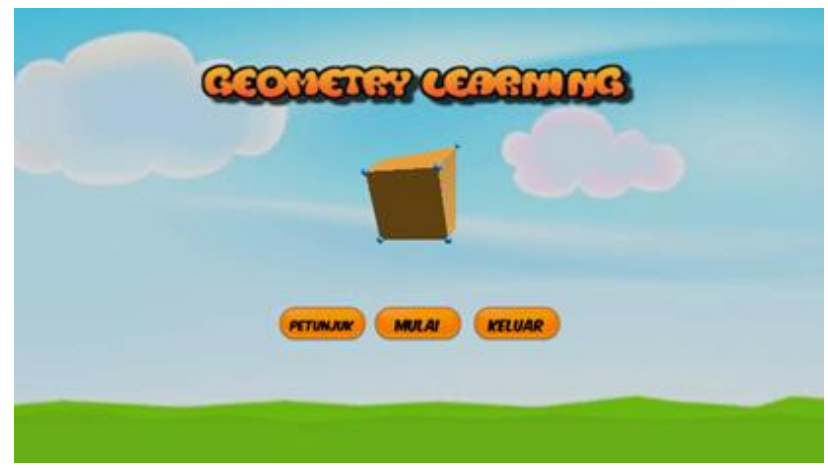

Fig. 2. The main display of AR geometry media

Figure 2 is the main display of the MB-AR that has been developed. On this initial display, there is an instruction menu of the MB-AR; a start and exit menu. The instruction menu explains how to operate the MB-AR; thus, the users are not confused about using the media. The start menu is used to open the MB-AR. It can be operated by logging in using the user ID and password that have been given to students. After successfully logging in, the media will go to the next display which is the material to learn 3-D shapes.

In Figure $3 \mathrm{a}$ and $3 \mathrm{~b}$, the material related to a rectangular prism is displayed. In this picture, students can understand the parts of a prism, such as the sides, diagonals, and ribs. In addition, because it applies AR technology, the image of the prism and its parts 
can be rotated according to the user's needs so they can see the structure of the prism in more detail.

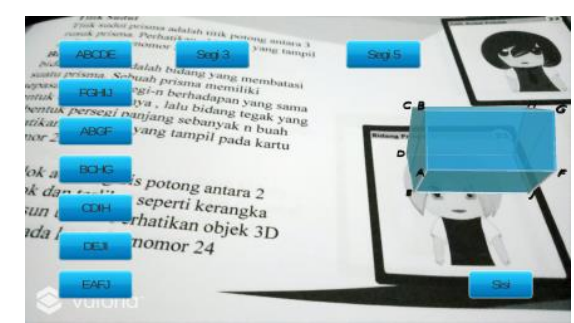

a)

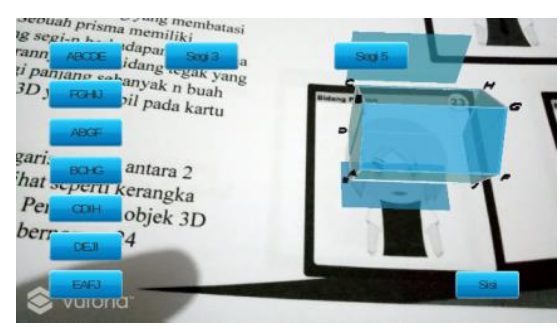

b)

Fig. 3. A three-dimensional view of a prism and its parts

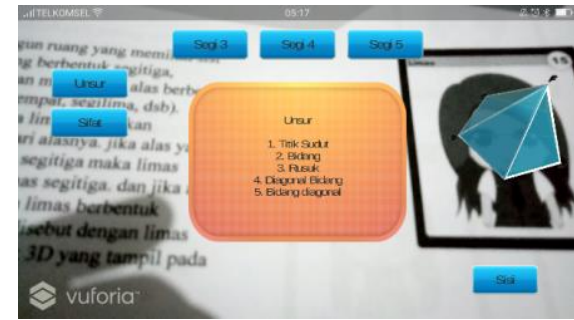

a)

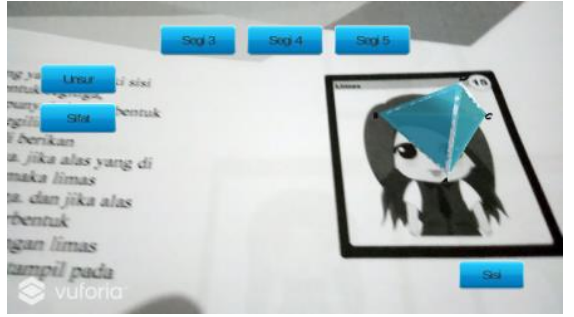

b)

Fig. 4. A three-dimensional view of a square-based pyramid

Figure 4 (a) and (b) show a square-based pyramid. In its AR display, some menus can be commenced by the user such as the formula to measure the area and volume of a square-based pyramid, display of the side, ribs, and diagonal parts of the 3-D object.

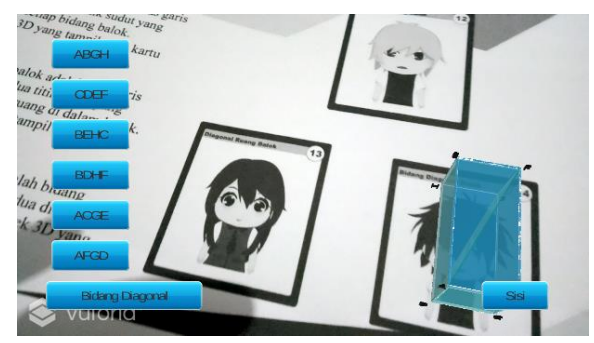

a)

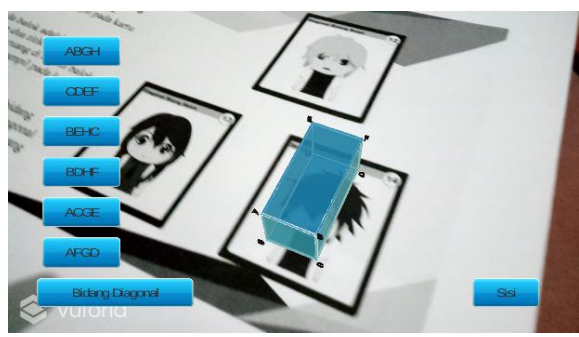

b)

Fig. 5. A three-dimensional view of a cuboid 
Figure 5 (a) and (b) shows a cuboid. In the display of the cuboid material, the user can try to identify parts of the cuboid, including the sides, ribs, diagonal, diagonal plane, as well as learn the formula to calculate the area and volume of the cuboid. Additionally, similar to the previous display, the user can rotate the camera position to get a full view of the 3-D object they are observing. With the advantages possessed by this MB-AR, the spatial ability of the users or students can be trained and improved [26].

Based on Figures 3, 4, and 5, MB-AR provides an opportunity for students to explore all parts of three-dimensional objects in geometry comprehensively so they can better understand the concept of three-dimensional objects. It is possible to occur because the MB-AR can be played according to the users' needs. Students can see almost all parts of the three-dimensional objects from various perspectives so it helps those who have been struggling in visualizing parts of geometric shapes by merely using immovable media or non-visual media. By using this MB-AR, students can overcome such problems. This MB-AR provides opportunities for students as if they are observing real three-dimensional objects through live experience because three-dimensional objects can emerge above the highlighted anime character image.

The live experience is a kind of learning experience that must be provided for students [27] because it will encourage high learning outcomes. Through live experience in learning three-dimensional objects using MB-AR, students' ability to observe spaces is expected to increase. Student' handbook is also provided in developing MB-AR materials. The handbook can be used by students as a guide in learning three-dimensional objects. In this handbook, the materials have been organized along with the anime image markers that can be highlighted by students' and teachers' camera phones. When the anime image is highlighted, a three-dimensional object will appear above the image. With this handbook, students can adjust their study time according to their needs.

Therefore, the use of MB-AR, which is equipped with a handbook as a guide for students in learning about three-dimensional objects, can both provide opportunities for students to explore AR-assisted material and help students to learn individually. Individual learning is a process that must be trained because it can improve students' problem-solving abilities [28]; [29].

\subsection{Students activities of spatial abilities}

Based on the implementation of the MB-AR at schools, an overview of how students learn in classrooms when using MB-AR is obtained. This learning activity is under the spatial ability of students which is investigated through classroom observation by using observation guidelines. Students' learning activities can be seen in Table 1 . 
Table 1. Students' activities towards the use of geometry using mobile-based AR

\begin{tabular}{|l|c|c|c|}
\hline \multicolumn{1}{|c|}{ Indicators } & $\mathbf{1}^{\text {st }}$ Phase & $\mathbf{2}^{\text {nd }}$ Phase & $\mathbf{3}^{\text {rd }}$ Phase \\
\hline $\begin{array}{l}\text { Able to analyze the geometrical characteristics and properties of three- } \\
\text { dimensional objects }\end{array}$ & $65 \%$ & $70 \%$ & $78 \%$ \\
\hline $\begin{array}{l}\text { Able to construct mathematical arguments concerning geometric rela- } \\
\text { tionships and so on }\end{array}$ & $69 \%$ & $72 \%$ & $75 \%$ \\
\hline $\begin{array}{l}\text { Able to identify, classify, and compare geometric objects } \\
\text { Apply the transformation and use it systematically in analyzing mathe- } \\
\text { matical situations }\end{array}$ & $74 \%$ & $77 \%$ & $80 \%$ \\
\hline $\begin{array}{l}\text { Use visualization, spatial thinking, and geometric model in solving } \\
\text { problems }\end{array}$ & $78 \%$ & $82 \%$ & $85 \%$ \\
\hline Average & $72 \%$ & $75 \%$ & $80 \%$ \\
\hline
\end{tabular}

Based on the observation that has been conducted, it is shown in Table 1 that there is an increase in all indicators. Students are found to have the ability to analyze the geometrical characteristics and properties of three-dimensional objects by using MBAR. This is indicated by an increase in spatial activity in the aspect of being able to analyze the characteristics and properties of 3D shapes from $65 \%$ to $78 \%$. In terms of constructing mathematical arguments concerning geometric relationships and so on, the increase has occurred from $69 \%$ to $75 \%$. This is proven by their ability to understand the diagonal calculation of the observed objects using MB-AR. They find it helpful since they can directly map the concept of diagonal even of the hidden parts of 3-D shapes which makes the calculation more accurate. It is in line with the statement in an earlier study that believes that the augmented reality mode performs significantly better than those in the simulation mode in achievements and visual thinking [30]. The percentage of students' ability in identifying, classifying, and comparing has also improved from $75 \%$ to $80 \%$. This means that by learning three-dimensional shapes geometric using MB-AR students can identify geometric shapes, including cube, prism, cuboid, and so on. Students are also able to classify the three-dimensional shapes clearly and compare one shape with another. Moreover, the percentage of applying the transformation and using it systematically in analyzing mathematical situations rises from $74 \%$ to $80 \%$. These results mean that they are able to transform various geometric shapes and use them systematically to analyze geometric shapes into mathematical situations. they understand the volume of three-dimensional shapes, determine diagonals of threedimensional shapes, and other parts Lastly, the percentage of the use of visualization, spatial thinking, and geometric model in solving problems has grown from $78 \%$ to $85 \%$. These results mean that they are able to solve three-dimensional visualization and solve three-dimensional problems. Overall, students' responses towards the use of geometry learning media based on AR have averagely increased in all phases from $72 \%$ to $80 \%$. this means that on average the spatial activity of students after learning three-dimensional geometry using MB-AR is in the high range. This shows that the use of MB-AR is effective in increasing students' spatial activity.

Furthermore, by using MB-AR, teachers can explain the material of three-dimensional objects clearer as this media assists them in showing the students the important parts of three-dimensional objects. A learning media is one factor that determines teachers' quality in teaching processes [31], [32]; thus, by utilizing a particular media, 
students are likely to understand the materials taught by the teachers faster [33]. This later leads to the growth of students' spatial learning activities.

\section{Conclusion}

According to the results of the study, it can be concluded that all students' spatial learning activities that are observed which consist of: the ability to analyze the geometrical characteristics; the ability to construct mathematical arguments geometrically; the ability to identify, classify, and compare geometric objects; the ability to transform and use the media systematically in analyzing mathematical situations geometrically; and the ability to visualize, think spatially, and model geometric concepts in solving problems, are seen to be increasing. This indicates that the use of MB-AR has effectively contributed to the growth of students' spatial learning activities.

\section{Acknowledgement}

Acknowledgement is due to The Department of Mechanical Engineering Education, Faculty of Technology and Vocational Education, Universitas Pendidikan Indonesia, that has provided the opportunity for the authors to conduct this research. This research is supported by the Directorate of Research and Community Service Directorate General of Research and Development Strengthening Ministry of Research, Technology and Higher Education following the Research Funding and Community Service Agreement Fiscal Year 2018.

\section{$7 \quad$ References}

[1] Jones, K. (2002). Issues in the teaching and learning of geometry. In Linda Haggarty (Ed) Aspects of teaching secondary mathematics: perspectives on practice. London: Routledge Falmer. https://eprints.soton.ac.uk/13588/1/Jones_teach_learn_geometry_2002.pdf

[2] J. Wai, D. Lubinski, and C. P. Benbow, "Spatial ability for STEM domains: Aligning over 50 years of cumulative psychological knowledge solidifies its importance," J. Educ. Psychol., vol. 101, no. 4, pp. 817-835, 2009. https://doi.org/10.1037/a0016127.

[3] G. Gittler and J. Glück, "Differential transfer of learning: Effects of instruction in descriptive geometry on spatial test performance.," J. Geometry and Graphics., vol. 2, no. 1, pp. 71-84, 1998.https://pdfs.semanticscholar.org/7623/6d74b8b37fe1f0e4a0de788bec0364ae7e8d.pdf

[4] Y.-T. Liao, C.-H. Yu, and C.-C. Wu, "Learning Geometry with Augmented Reality to Enhance Spatial Ability," in 2015 International Conference on Learning and Teaching in Computing and Engineering, 2015, pp. 221-222. https://doi.org/10.1109/latice.2015.40

[5] Telima Adolphus, "Problems of Teaching and Learning of Geometry in Secondary Schools in Rivers State, Nigeria," Internationa Journal of Emerging Sciences., vol. 1, no. 2, pp. $143-$ 152, 2011. https://www.stir.ac.uk/research/hub/ publication/510419.

[6] H. Baytiyeh, "Students' Use of Mobile Technologies," Int. J. Inf. Commun. Technol. Educ., vol. 14, no. 1, pp. 73-85, Jan. 2018. http://hdl.handle.net/1893/26189. 
[7] Wahyudin, Y. Wihardi, and A. Agustan, "Implementation of cyber-blog system to improving concept understanding in algorithm for students," in 2015 International Conference on Science in Information Technology (ICSITech), 2015, pp. 100-105. https://doi.org/10. 1109/icsitech.2015.7407785.

[8] C. S. C. Dalim, A. Dey, T. Piumsomboon, M. Billinghurst, and S. Sunar, "TeachAR: An Interactive Augmented Reality Tool for Teaching Basic English to Non-Native Children," in 2016 IEEE International Symposium on Mixed and Augmented Reality (ISMARAdjunct), 2016, pp. 82-86. https://www.semanticscholar.org/paper/TeachAR\%3A-An-Interactive-Augmented-Reality-Tool-for-Dalim-Piumsomboon/85fb328357eeeb88e3a33ccab83646419aeca2d4. https://doi.org/10.1109/ismar-adjunct.2016.0113

[9] M. A. Alkhateeb and A. M. Al-duwairi, "The Effect of Using Mobile Applications (GeoGebra and Sketchpad) on the Students' Achievement," vol. 14, no. 3, pp. 523-533, 2019. https://doi.org/10.29333/iejme/5754.

[10] D. Schmalstieg and I. Systeme, "Geometry Education with Augmented Reality," Technology,2004, http://citeseerx.ist.psu.edu/viewdoc/download?doi=10.1.1.72.1770\&rep=rep1\& type $=$ pdf .

[11] P. Sorokowski, A. Sorokowska, A. Oleszkiewicz, T. Frackowiak, A. Huk, and K. Pisanski, "Selfie posting behaviors are associated with narcissism among men," Pers. Individ. Dif., vol. 85, pp. 123-127, 2015. https://doi.org/10.1016/j.paid.2015.05.004

[12] Bako, M. (2003). Different projecting methods in teaching spatial geometry. Retrieved July 4, 2007 from http://www.dm.unipi.it/ didattica/CERME3/proceedings/ Groups/TG7/TG7 _Bako_cerme3.pdf.

[13] Gutierrez, A. (1992). Exploring the links between van Hiele levels and 3-dimensional geometry. Structural Topology, 18, pp. 31-48, https://www.uv.es/Angel.Gutierrez/archivos1/textospdf/Gut92a.pdf.

[14] Kenney, P.A., \& Kouba, V.L. (1997). What do students know about geometry? In P.A. Kenney \& E.A. Silver, Eds., Results from the sixth mathematics assessment of the National Assessment of Educational Progress, (pp. 1-15). Reston, VA: The National Council of Teachers of Mathematics, Inc.

[15] N. Guzel and E. Sener, "High school students' spatial ability and creativity in geometry," vol. 1, no. 2009, pp. 1763-1766, 2010.https://doi.org/10.1016/j.sbspro.2009.01.312

[16] G. Sunzuma and A. Maharaj, “In-service Teachers' Geometry Content Knowledge: Implications for how Geometry is Taught in Teacher Training Institutions," vol. 14, no. 3, pp. 633-646, 2019. https://doi.org/10.29333/iejme/5776

[17] Diocese of Toledo Mathematics Course of Study 2010 Geometry and Spatial Sense Standard. [Online]. Tersedia: http://www.cyss.org/Schools/CofS/ MathPilotByStandards/ Pilot MathGeometry SpatialSense.pdf.

[18] Dunleavy, M., Dede, C., \& Mitchell, R. (2009). Affordances and limitations of immersive participatory augmented reality simulations for teaching and learning. Journal of Science Education and Technology, 18(1), 7-22. https://doi.org/10.1007/s10956-008-9119-1

[19] Milgram, P., \& Kishino, F. (1994). A taxonomy of mixed reality visual displays. IEICE Transactions on Information Systems, E77-D (12), 1321-1329, https://cs.gmu.edu/ حduric/cs499/Readings/r76JBo-Milgram_IEICE_1994.pdf.

[20] Tekedere, H., \& Göker, H. (2016). Examining the effectiveness of augmented reality applications in education: A meta-analysis. International Journal of Environmental \& Science Education, 11(16), 9469-9481, https://eric.ed.gov/ ?id=EJ1118774.

[21] Sumadio, D. D., \& Rambli, D. R. A. (2010). Preliminary evaluation on user acceptance of the augmented reality use for education. In Proceedings of second international conference 
on computer engineering applications (pp. 461-465). https://doi.org/10.1109/iccea.2010.239

[22] Chiang, T. H., Yang, S. J., \& Hwang, G.-J. (2014). An augmented reality-based mobile learning system to improve students' learning achievements and motivations in natural science inquiry activities. Journal of Educational Technology \& Society, 17(4), 352-365, https://www.researchgate.net/journal/1436-4522 Educational Technology Society.

[23] Serio, Á., Ibáñez, M. B., \& Kloos, C. D. (2013). Impact of an augmented reality system on students' motivation for a visual art course. Computers and Education, 68, 586-596. https://doi.org/10.1016/j.compedu.2012.03.002

[24] Agrawal, M., Kulkarni, A., Joshi, S., Tiku, N 2015 Augmented Reality. International Journal of advance Research in Computer Science and Management Studies: India, http://www.ijarcsms.com/docs/paper/volume3/issue2/V3I2-0030.pdf.

[25] Pressman, R. (2001). Software engineering: a practitioner's approach / Roger S. Pressman.-5th ed.p. cm. - (McGraw-Hill series in computer science) Includes index. ISBN 007-365578-3 1. Software engineering. I. Title. II. Series., 2001

[26] Rohendi, D, Septian, S, and Sutarno, H. (2017) The Use of Geometry Learning Media Based on Augmented Reality for junior High School $\mathrm{S}$ https://doi:10.1088/1757899X/306/1/012029.students. IPO Conf Series: Materials Science and Engineering 306(2018). https://doi.org/10.1088/1757-899x/306/1/012029

[27] Dale, Edgar, (1969) Audio Visual Methods in Teaching, New Yorg: Holt, Rinehart and Winston Inc. The Dryden Press.

[28] Fahyuddin, Liliasari, Sabandar, J., Muhamad A. Martoprawiro, Perbandingan Metode Kolaborasi Dengan Contoh Tugas Dan Belajar Individual Dalam Pengembangan Kemampuan Pemecahan Masalah Kimia Cakrawala Pendidikan Februari 2015, Th. Xxxiv, No. 1. https://doi.org/10.21831/cp.v36i1.10402

[29] Sharifah Osman 1*, Che Nurul Azieana Che Yang 2, Mohd Salleh Abu 1, Norulhuda Ismail 1, Hanifah Jambari 1, Jeya Amantha Kumar (2018). Enhancing Students' Mathematical Problem-Solving Skills through Bar Model Visualisation Technique. International Electronic Journal of Mathematics Education, e-ISSN: 1306-3030, Vol 13, No. 3, 273-279. https://doi.org/10.12973/iejme/3919

[30] Osamah (Mohammad Ameen) Aldalalah, Zyad Waleed Mohamed Ababneh, Ali Khaled Bawaneh. (2019). Effect of Augmented Reality and Simulation on the Achievement of Mathematics and Visual Thinking. International Journal of Emerging Technologies in Learning (iJET), vol 14 No. 18. https://doi.org/10.3991/ijet.v14i18.10748

[31] Pardimin and Sri Adi Widodo, Development Comic Based Problem Solving in Geometry, International Electronic Journal of Mathematics Education, e-ISSN: 1306-3030. 2017, Vol 12, No. 2, 233-241, https://www.iejme.com/article/ development-comic-based- problemsolving-in-geometry.

[32] Nuanmeesri, S., (2018). The Augmented Reality for Teaching Thai Students about the Human Heart, International Journal of Emerging Technologies in Learning (iJET), vol 13 No. 06. https://doi.org/10.3991/ijet.v13i06.8506

[33] Fezile Ozdamli, Cigdem Hursen. (2017). An Emerging Technology: Augmented Reality to Promote Learning. International Journal of Emerging Technologies in Learning (iJET), vol 12, no. 11. https://doi.org/10.3991/ijet.v12i11.7354 


\section{Authors}

Dr. D Rohendi is currently an associate professor at the Department of Mechanical Engineering Education, Faculty of Technology and Vocational Education. He is also a lecturer in postgraduate program of Technical and Vocational Education Study Program at Universitas Pendidikan Indonesia (UPI). He completed a master degree in Computer and Information Technology from Universitas Gadjah Mada, Yogyakarta, Indonesia, in 2000 and his doctoral degree in Mathematics Education from Universitas Pendidikan Indonesia, Indonesia in 2009. He has published some mathematics education papers especially the use of multimedia in teaching and learning mathematics, computer education, and innovation media in some international journals also in IOP Conference Series and Atlantis Press. Email: dedir@upi.edu

Y Wihardi is a lecturer at the Department of Computer Science Education, Faculty of Mathematics and Sciences Education at Universitas Pendidikan Indonesia (UPI). He has published some computer science papers related to programming, computer vision, and computer science in some international journals and also in IOP Conference Series and Atlantis Press.

Article submitted 2020-01-05. Resubmitted 2020-03-12. Final acceptance 2020-03-20. Final version published as submitted by the authors. 